\title{
Evaluating the University's Governing Board: A Comprehensive Review of Its Domains and Indicators
}

\author{
Haniye Sadat Sajadi ${ }^{1}$, Mohammadreza Maleki ${ }^{2}$, Hamid Ravaghi ${ }^{2}$, Steve o. Michael ${ }^{3}$, Mohammad Hadi ${ }^{4 * *}$ \\ ${ }^{1}$ Health Management and Economics Research Center, Isfahan University of Medical Sciences, Isfahan, Iran \\ ${ }^{2}$ Department of Health Services Management, Iran University of Medical sciences, Tehran, Iran \\ ${ }^{3}$ Provost and Professor, Arcadia University, Pennsylvania, USA \\ ${ }^{4}$ Chancellery Office, Isfahan University of Medical sciences, Isfahan, Iran \\ *Corresponding author: hadi@mui.ac.ir
}

Received September 05, 2014; Revised September 30, 2014; Accepted October 08, 2014

\begin{abstract}
Background: Existing evidence with regard to the indicators of board performance evaluation of the University demonstrated that a comprehensive review of literature is required. The aim of this article is to add to the literature on performance evaluation of the universities' governing boards by providing a summary of literaturebased perspectives. Methodology: Systematic literature searches were undertaken, and relevant studies identified using specific inclusion and exclusion criteria. The selected studies were appraised, and their findings synthesized. Principal Findings: Fourteen relevant studies were identified, mostly from the USA. Fifty six indicators, categorized in seven domains, were identified to evaluate board performance in different universities. Conclusion: Our results showed a gap in the literature with respect to the performance evaluation of universities' governing boards. Given the unique context of these universities, it is suggested that more research need to be done in order to understand the indicators of the board performance evaluation in these institutions.
\end{abstract}

Keywords: performance, evaluation, trustee's board, university, indicator

Cite This Article: Haniye Sadat Sajadi, Mohammadreza Maleki, Hamid Ravaghi, Steve o. Michael, and Mohammad Hadi, "Evaluating the University's Governing Board: A Comprehensive Review of Its Domains and Indicators." American Journal of Educational Research, vol. 2, no. 10 (2014): 892-897. doi: 10.12691/education-2-10-7.

\section{Introduction}

The increasing importance of university's role in our modern economies has added new challenges for higher education management. These new challenges with an increasing demand for greater institutional efficiency and effectiveness put new requirement for professional management, innovative forms of organization [1] and creative solutions to emerging institutional problems.

There is a growing focus on university governance in a renewed effort to solving myriads of institutional management problems. Today there is much more attention being paid to the overall university governance in general and to the role of the governing board in particular [2]. This is so because governing boards play the pivotal role in governance as they help to ensure that management achieves the stated goals and objectives and ensure the survival of the institution [3]. Furthermore, the future of higher education is entrusted to governing boards [4]. The governing board is the most important kind of boards [5] in higher education. It is identified as the decision- and policy-making group that sits at the helm of an institutional structure. The Board possesses the highest organizational authority and is accountable for all organizational activities and outcomes [6].

Given the critical role that the board plays in university performance, it is no wonder that how to evaluate the performance of the board has become a matter of interest for higher education scholars. Measuring board performance is a difficult activity [7], however, it can help a board to identify its strengths and weakness and help them to adopt required actions that may result in improving effectiveness and/or efficiency. Therefore, improving the board's performance is likely lead to greater university effectiveness [7,8,9,10]. Like every performance evaluation, deciding about the content of the evaluation is a difficult, but critical component.

What constitutes the content of the board performance evaluation has been examined widely in the literature [7,9,11-22]. There is now a growing literature on this topic, especially outside the higher education sector, but still relatively spare within the higher education. Some authors have also commented that much of the literature on this topic in higher education is descriptive and anecdotal in nature with limited empirical analysis e.g. [23]. The purpose of this article is to add to the literature on the performance evaluation of the governing boards by providing a summary of the current variables covered in previous studies.

The work reported in this article was a part of a larger study for a doctoral dissertation. Hence, every stage of the work was under the guidance of dissertation supervisors and international experts who have published on this subject and whose publications inform the work. To use this template, you will need to (1) apply the embedded 
styles to each paragraph-level item in your manuscript or (2) use the specifications shown in Table 1 to format your manuscript, with this template as a visual guide. Information about paper submission is available from the Journal website.

\section{Main Text}

\subsection{How to Retrieve Related Evidence}

The scope of this review was to identify studies relating to evaluating board performance in universities. Only empirical studies undertaken in the universities and educational institutions published in English language and until 2011 were included. Different strategies used to identify relevant studies including searching of electronic databases, reference scanning of relevant papers, handsearching of the key journals and consultations with experts and universities where studies have been conducted. Several key databases using suitable keywords were searched. Finally, a general Internet search using Google and Yahoo search engines was undertaken to find further information from unpublished research studies. The initial search was conducted in December 2011 and was updated in September 2012. To eliminate duplication, results from the different databases were placed into an Endnote software package. Because the literature on the board performance evaluation was mainly discursive and the studies rarely include objective measurable outcomes commonly used in quantitative research, a narrative approach was used to synthesize the results of the studies. The input-process-output framework, that is comprehensive framework to guide holistic evaluation of board performance, was used to summarize and interpret the study findings.

\subsection{The Characteristics of Included Studies}

Description of Studies: Once duplicates were removed, the search identified 5711 papers. During the initial stage, 5592 papers were excluded on examination of the title and abstract. In the next stage, the complete texts of the remaining papers (119) were assessed against the inclusion criteria and a further 102 studies were excluded. Moreover, three studies could not be included, due to failure to access their full text in spite of three attempts to obtain them. Finally, 14 primary studies were selected for the study. A detailed summary of the included studies is presented on Table 1.

Sectoral Coverage: Studies have been conducted across different kind of universities including: private [24]; public [4,25-31]; and independent [32] universities. The setting of some studies was combination of all $[32,33]$ or some sectors [23]. One study has been conducted in various nonprofit sectors including the higher education [33].

Time and Place of publication: Regarding to the time of publication, there has been a growing interest in this topic since the early 1970s. This interest has mainly increased after 2000. Most studies have been carried out in USA [4,23,24,26-34]. One study was conducted and published in Iran [25]. Also, one study was conducted in Canada [35].

The Goals of the Selected Studies: The goals of the selected studies were different. Five studies had focused only on identifying indicators and domains of the board performance evaluation [4,26,29,31,34]. The focus of other five studies was merely on evaluating the board performance [24,27,28,30,33]. The remaining four studies explored both identifying the board performance indicators and evaluating the board performance on the basis of the identified indicators [23,25,32,35].

Table 1. summary of the included studies

\begin{tabular}{|c|c|c|c|}
\hline Author/s & Setting & Sample characteristics & Method \\
\hline $\begin{array}{l}\text { Davis et } \\
\text { al., } 1974\end{array}$ & $\begin{array}{l}\text { all sectors, } \\
\text { US }\end{array}$ & $\begin{array}{c}282 \text { college president (RR: } \\
\text { 66\%), } 4051 \text { college trustees } \\
\text { (RR: 37\%), random } \\
\text { sampling }\end{array}$ & quantitative \\
\hline $\begin{array}{c}\text { Likins, } \\
1979\end{array}$ & $\begin{array}{l}\text { private } \\
\text { sector, US }\end{array}$ & $\begin{array}{c}91 \text { universities, } \\
\text { chairpersons of boards and } \\
\text { presidents }\end{array}$ & quantitative \\
\hline $\begin{array}{l}\text { Chait et } \\
\text { al., } 1987\end{array}$ & $\begin{array}{l}\text { all sectors, } \\
\text { US }\end{array}$ & 61 trustees & quantitative \\
\hline $\begin{array}{l}\text { Holland et } \\
\text { al., } 1989\end{array}$ & $\begin{array}{l}\text { independent } \\
\text { sector, US }\end{array}$ & Trustees, purposively & Mix \\
\hline $\begin{array}{l}\text { Williams } \\
\text { et al., } 1992\end{array}$ & $\begin{array}{c}\text { public } \\
\text { sector, US }\end{array}$ & $\begin{array}{c}30 \text { community presidents } \\
\text { and trustees (RR: 93\%), } \\
\text { purposively }\end{array}$ & qualitative \\
\hline $\begin{array}{c}\text { Myers, } \\
1997\end{array}$ & $\begin{array}{c}\text { public } \\
\text { sector, US }\end{array}$ & $\begin{array}{l}27 \text { multi campus CEO and } \\
\text { trustees }\end{array}$ & qualitative \\
\hline $\begin{array}{c}\text { Kinkel, } \\
1998 \\
\end{array}$ & $\begin{array}{c}\text { public } \\
\text { sector, US }\end{array}$ & $\begin{array}{c}\text { trustees and governors, } \\
\text { purposively }\end{array}$ & qualitative \\
\hline $\begin{array}{c}\text { Michael et } \\
\text { al., } 2000\end{array}$ & $\begin{array}{c}\text { different } \\
\text { sectors, US }\end{array}$ & 686 trustees (RR: 71\%) & quantitative \\
\hline $\begin{array}{l}\text { Sortor, } \\
2002\end{array}$ & $\begin{array}{l}\text { public } \\
\text { sector, US }\end{array}$ & $\begin{array}{l}42 \text { community college } \\
\text { presidents, trustees and } \\
\text { board chairpersons, } \\
\text { purposively }\end{array}$ & $\begin{array}{c}\text { qualitative } \\
\text { and } \\
\text { quantitative }\end{array}$ \\
\hline $\begin{array}{l}\text { Schenk, } \\
2003\end{array}$ & $\begin{array}{c}\text { public } \\
\text { sector, US }\end{array}$ & 90 trustees, purposively & Mix \\
\hline $\begin{array}{l}\text { Gill et al., } \\
2005\end{array}$ & $\begin{array}{l}\text { nonprofit } \\
\text { organizatio } \\
\text { ns, Canada }\end{array}$ & $\begin{array}{l}281 \text { board members and } 31 \\
\text { executives directors from } \\
32 \text { nonprofit organizations }\end{array}$ & quantitative \\
\hline $\begin{array}{l}\text { CHEPA, } \\
2006\end{array}$ & $\begin{array}{c}\text { public } \\
\text { sector, US }\end{array}$ & $\begin{array}{c}132 \text { leaders in higher } \\
\text { education }\end{array}$ & qualitative \\
\hline $\begin{array}{l}\text { Kezar, } \\
2006\end{array}$ & $\begin{array}{c}\text { public } \\
\text { sector, US }\end{array}$ & $\begin{array}{l}65 \text { different stakeholders of } \\
\text { boards, snowball }\end{array}$ & qualitative \\
\hline $\begin{array}{c}\text { Damari } \\
\text { et.al, } 2010\end{array}$ & $\begin{array}{c}\text { public } \\
\text { sector, Iran }\end{array}$ & $\begin{array}{l}860 \text { enactments, trustees } \\
\text { and the officers in charge } \\
\text { of board secretariats }\end{array}$ & quantitative \\
\hline
\end{tabular}

Research Methods of the Selected Studies: The research method of six studies was quantitative [23,24,25,33,34,35]. The qualitative methods had been employed in five studies $[4,26,27,29,31]$. Three studies employed mix method (qualitative-quantitative) [28,30,32]. The qualitative studies have used single case study [30], multiple case studies [32], Delphi technique [31] and grounded theory [27]. Questionnaire, interviews, document analysis, observations and focus group were employed in these studies to gather data.

Theoretical Frameworks of the Selected Studies: Ten studies had no explicit theoretical framework to explain the board performance evaluation. However, seven studies did use different frameworks, including Association of Governing Boards (AGB) framework [24,33], Chait et al. framework [27,28,30], Shultz matrix framework [26] and a self-developed framework by researchers [23].

\subsection{The Domains and Indicator of the Board Performance Evaluation}

As discussed earlier, an input-process-output approach was employed to organize the board performance domains and indicators identified in the literature. Fifty six 
indicators categorized to seven domains were emerged from the literature review.

Input dimension: Three domains were recognized in the input dimension containing trustees, leadership and structure. Fifteen indicators were reported in trustees' domain. The first three indicators were classified in one group titled trustees knowledge, awareness and understanding. These three indicators were trustees awareness about their tasks, roles and responsibilities as a member of trustee board [34], understanding the higher education context and culture [26,27,28,30,32,34] and recognition the complexities and differences between the administration of higher education and that of the other organizations [23,29,34].

The next group of indicators in trustees' domain referred to trustees' competence. Five competences reported in the studies are the analytical competence [27,28,30,32,34], the systemic thinking ability [4,26,34], team working ability [35], resources attracted [23] and political competence [27,28,30,32,34].

Trustees experience was another indicator in this domain identified by three studies [26,29,34]. Another indicator related to trustees' characteristics was Trustees' participation. Three indicators of trustees' involvement were found in the selected studied that contain the time devoted to trusteeship affairs [4,23,26,31,34], timely and regular attendance at the board meetings [34] and active participation in the board meetings [34]. Two studies indicated directly that trustees' commitment and willingness to the institution mission could be considered as the board performance evaluation [29,31,34]. The two remaining indicators of trustees' domain, shown by four studies, were classified in a group, labeled trustees' influences. These indicators refer to the trustees' direct and indirect influences to the welfare of their institution. The first one was political influences [23] and the second indicator was trustees' external relationship, especially those with legislatures [26].

Trustees' leadership was the second domain of the input dimension. Given included studies, only one indicator could be defined for this domain. It was the strength and effectiveness of the board chair [4,26,29,34].

The third domain related to input was structure. Unlike the two prior domains that focused on individual characteristics, structure domain concentrated more on board as entity. Seven different indicators of the board performance evaluation were identified: board composition [25,26,29,35], board diversity of perspectives $[26,29,34]$, geographic representation/regional differences [26], use of committee structure $[4,25,26]$, having a clear, defined and update board mission [26,34], clear board roles, responsibilities and tasks [4] and ethics code charter [24,31,33].

Process dimension: Internal process and social/board dynamic were two domains that have been noted in the selected studies. As stated by Kane et al. [36], by term process we mean "the systematic series of tasks and activities undertaken by the board and to the overall systematic management of the board's work". In this domain twelve indicators, categorized in four groups, were found in the relevant studies. The first group was labeled as board meeting. In this regard, several indicators were emerged from the studies: the quality of agenda, the quality, timeliness and relevance of supporting information of agenda items [4,31,34], professional suggestions and ideas of trustees [34], well-managed board meeting [33,36], active, vigorous and sufficient debates and discussion of key issues in board meetings $[4,31,34]$ and decision making process [4,26,34,35].

Second group of processes indicators were named as selection, rotation and replacement processes. The first indicator in this group was the process of trustees' member selection and appointment as well as re (de)selection $[25,26,35]$. The second was the process of rotation of the chair of the board [4]. Selecting and appointing a CEO/president was the last indicator in this group [26,31]. The board development was the third group of process indicators. There were two important and frequently cited indicators in this group--board orientation [4,26,31] and board education [4,27,28,30,32].

The last group of process indicators was board evaluation process. Two indicators were placed in this group. First is the process of ongoing board evaluation $[4,26,31,34,35]$ and the second was the process of central supervision of boards' performance [25].

The social/board dynamic was the second domain of the process dimension. Nine indicators were identified in the relevant selected studies regarding this domain. Most of these indicators of the social/board dynamic focused on board relationships including the trustees' interpersonal relations [4,23,26,27,28,30,32,34,33], CEO/president and trustees relations $[4,23,26,31,34]$, the $\mathrm{CEO} /$ president and board chair relations [4], the board relationship with its stakeholders including faculty [23,26,31,34], students $[23,26,31,34]$, society $[4,26,31]$ and key legislative and governor bodies [23,26,31,34].

Managing conflicts was another indicator identified in the social dynamic domain by two studies [4,29]. Acting as a decision making group was the last indicator of this domain. Acting as a team lets board lead as a collective body. This reduces the chance for other managerial teams to gain too much power $[4,27,28,30,32]$.

Output dimension: This section identifies domains that were distinguished by time. The first category relates to short-term results and is called outputs, while those that relate to the long-term results are called outcomes in this study. Eight indicators were defined in the outputs domain. The first group of five indicators was related to the main outputs of the boards, which are various functions, or tasks performed by the board and the degree to which boards are successful in carrying out their tasks. The indicators of this group were the most frequent and important indicators of the board performance evaluation and effectiveness cited in the relevant selected studies [25,26,31,34].

The second group of outputs indicators was named as the board decision-making. In this group, the first indicator was strategic direction of the board decisions, policies and plans. The importance of this direction was emphasized by several studies as a vital indicator of the board performance evaluation [25,26,27,28,30,32,34,35]. The second indicator was the extent to which enactments have been enforced [25]. Lastly, with respect to the output domains, the frequency of the board meeting has been shown by a few studies as an indicator of the board performance [34].

Four indicators were identified regarding to the last domain of the output dimension. The first two of them, 
institution performance and $\mathrm{CEO} /$ president performance, were classified in a group named performance. Some studies have already addressed these indicators as indicators of the board performance evaluation $[26,31,34,35]$.The third outcomes indicator was found as the extent to which the institution's goals have been achieved. One study pointed to this indicator [25]. The last indicator refers creating a culture of excellence at the system, noted only by one study [26]. It is mentioned that an effective board can build, maintain and improve a culture of trust and honesty at the organization.

\section{Discussion}

This is the first comprehensive, system-based literature review exploring the domains and indicators of board performance evaluation in universities. This study synthesized the available evidence within higher education and compares it with the existing literature derived from the other sectors. We have highlighted key issues with respect to the theoretical frameworks and have summarized the results of the selected studies. These are discussed each in turn as follows.

First of all, related to the nature of studies, a few number of the evidence (only 14 eligible works out of 119 potential works) demonstrates that, most of current literature about the performance evaluation of universities' board were descriptive, based on writer's perspective. Few of the articles on board evaluation are based on empirical data. This conclusion aligns with one of the writers who concluded that one of problems with the board performance literature refers to this fact that they are based on single anecdotes-consultants' advice or words of wisdom from former board members [4]. Such limitation has been observed beyond the universities context. As Cornforth [11] stated, much of the literature on the effectiveness of governing board in nonprofit organization is based on personal opinions reflecting personal experiences of the writers. This phenomenon is changing as new studies based on empirical investigations are emerging. As our review indicated, the number of board performance studies has been increasing since 2000. Also, there has been a slow but steady trickle of the systematic empirical studies examining nonprofit and corporate board performance since the late 1980 's. This growth is to be expected given the increasing importance of the role of boards and the increasing emphasis on accountability in the universities. However, although the number of studies is increasing, more investigation about board performance evaluation is needed.

The second finding of this review is related to the frameworks of the board performance evaluation. Similar to the literature outside the higher education sector, the reading of the selected studies reveals that there is no agreement among researchers on the best, integrated and comprehensive framework for identifying, measuring and discussing the board performance evaluation [37]. It seems that the differences in context in which the board operates are responsible for this. The situation in each institution is different. Therefore, scholars that studied specific institutions using case study method tend to lack broad frameworks that can be used to assess a wide range of indicators relevant to the board performance evaluation.
The role of the context and its relationship with effective board performance has been examined by prior researches $[38,39]$. So, special attention is recommended to develop and use an appropriate framework for the board performance evaluation given the context.

With respect to this finding, most well-known and popular frameworks of the board performance evaluation, which had been used in different sectors, were identified. Two predominant frameworks for evaluating performance and understanding effectiveness for the university's boards were the AGB [40] framework and Chait et al. one. Beyond the higher education context, the most three dominant frameworks have been developed by Carver, Conger et al. [41] and Robinson. Although it seems these frameworks differ in their overall orientation, more precise attention to these models highlighted a great deal of similarity between the different model's prescriptions. Given these similarities, we can conclude that although most authors identified areas of the board performance evaluation, only a handful of authors have proposed and developed comprehensive models to assess board performance. This implies the need and necessity of developing a complete framework to evaluate board performance, especially in the universities context. Perhaps employing input-process-output framework to evaluate board performance would be useful regarding to this need.

The third finding of present review was concerned about the dimensions of the board performance evaluation. This review showed that process dimension and its domains, similar to literature in nonprofit sector, have received more attention by researchers and scholars to evaluate board performance in universities. Perhaps it is because focusing on process dimension for the board performance is more feasible and usable approach. Moreover, it can be said that because boards can add value to organizations through the transition process, attention to this dimension is important. This conclusion has been mentioned by prior studies [4]. The input dimension and its domains have also taken into account to assess board performance, both in the universities context and outside the universities. It is perhaps because these indicators, especially those which relate to the structure domain, are directly observable; hence their measure is more reliable and valid [18]. Lastly, the focus of board performance evaluation plans of the studies was less on the output dimension and its domains. It seems the difficulty of considering outcome dimension, to isolate and measure this dimension, or operationalized it in an easy manner, prevents many scholars to consider it. There is not such difficulty in the literature of corporate board performance evaluation [4]. Since, most of these literature have focused on outcome dimension and as many researchers reported, small minority of them have focused on board process by delving into the "black box" for evaluating its performance [13,15,18].

In conclusion, it can be stated that due to the different context and the lack of comprehensive model for the board performance measuring, researchers from diverse disciplines have focused on various dimensions of the board performance assessment. In other words, as Nicholson and Kiel [42] stated, everyone who is working with boards has developed an implicit framework to guide their decision-making. These frameworks are generally 
tacit and built from former experiences resulting in "partial framework" that differs in quality and complexity with the framework developer. This displayed again the importance of developing a generic framework for the board performance evaluation, which considers all aspects together.

The next finding of this review was about the domains of board performance evaluation. With the input-processoutput approach in mind and the mapping of the selected studies, seven domains were recognized including trustees, leadership and structure (in the input dimension); internal process and social/board dynamic (in the process dimension); outputs and outcomes (in the output dimension). Such classification with some differences was observed in those literatures which have employed inputprocess-output framework to investigate board performance. For example, Cornforth [11] categorized different factors which have been proposed that affect nonprofit board performance in board members (in the inputs dimension); board structures and processes (in the process dimension); and board tasks and functions (in the output dimension). In another classification which has been suggested to assess corporate board performance, these domains contained board composition (in the inputs); board systems and structures (in the processes); board performance (in outputs); and corporate performance (in outputs) [16]. Such differences are not unexpected. It is because, as we noted earlier, the classification of a variety domains for the board performance evaluation is affected mostly by the researcher's view and its definition of every category/component.

The final findings of our review concerned the indicators of the board performance evaluation in each dimensions. Most of identified indicators in the universities, aligned with those in other sectors. This similarity was especially more in indicators of structure, internal process, social dynamic and output domains. Most of these domains' indicators were well-researched characteristics that are considered to have an important impact on the board performance. It is perhaps because these indicators mostly focus on some characteristic of the board as a team. Less similarity observed on indicators of the trustees and leadership domains. It is worth noting that the identified indicators related to the trustees' domain in the universities context were more than the other sectors. In addition, many studies have emphasized on these indicators to evaluate board performance.

Finally, minimum similarity was emerged in outcome's indicators. While the numbers of studies which have considered outcome's indicators for the evaluation of the university board performance were handful, many studies, especially in corporate literature, have considered these indicators for the board evaluation. It is perhaps because of simplicity of defining and measuring outcomes indicators in corporate sector. In corporate literature, the long-term financial succession was the most frequent indicator that regarding the mission of the universities cannot be studied as an indicator for the board performance.

\section{Conclusion}

In sum, the key conclusion which can be drawn from this literature is that there is no "one best approach/framework" for evaluation the board performance, since the indicators of the board performance depend on organizational context. However, it seems that the input-process-output framework can be more useful. It is because in comparison with available frameworks, this framework is a generalized one and can assist us to conceptualize how boards work and what we can do in order to improve board performance in every context. Hence, if we want to evaluate a board in the corporate sector, we focus more on outcome indicators. While, if we consider a board to evaluate in public sector, such as university context, we emphasis more on input and process indicators. This framework also considered board performance indicators as a set of interrelated dimension where a change in one dimension affects others. As a result, board performance problems can be diagnosed and based on it, suitable plans for board performance improvement are proposed. Lastly, employing this framework can cover both individual and whole level of the board for the performance evaluation (Figure 1).

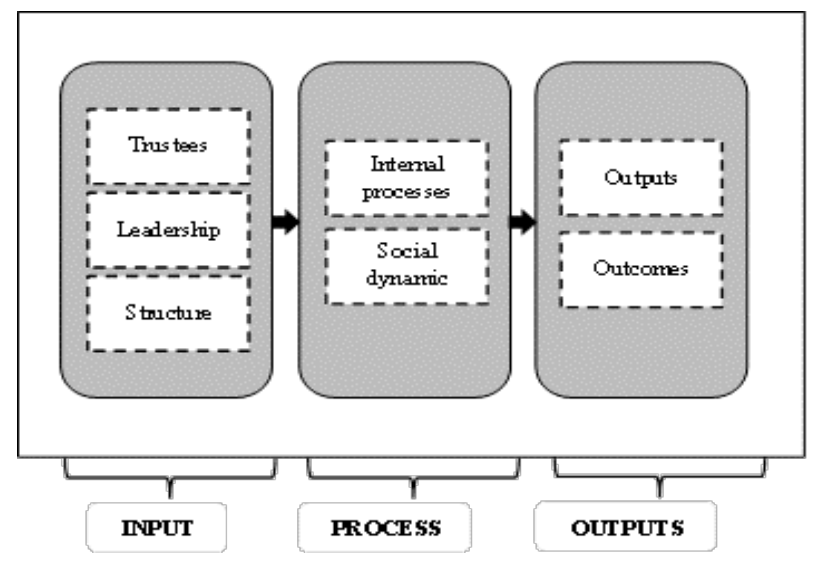

Figure 1. The input-process-output framework to board performance evaluation

This review also revealed a gap in the literature with respect to the performance evaluation of the higher education governing boards. Given the unique context of the universities, it is suggested that more research need to be done in order to understand the indicators of the board performance evaluation.

\section{Acknowledgement}

This study was part of PH.D dissertation supported by Iran University of Medical Sciences (Grant no: 1390/628).

\section{References}

[1] Kerr C, Gade ML. The Guardians: Boards of Trustees of American Colleges; What They Do and How Well They Do It. Washington DC: Association of Governing Boards; 1989.

[2] Kelleher MF. The Effectiveness of Governing Bodies. Paper presented at the Governing bodies of higher education institutions: Roles and responsibilities, Paris; 2006.

[3] Langabeer JR, Galeener CA. Measuring board activity in governance of not-for-profit healthcare. TPHA Journal. 2008; 60(1): 22-25.

[4] Kezar AJ. Rethinking Public Higher Education Governing Boards Performance: Results of a National Study of Governing Boards in the United States. Journal of Higher Education. 2006; 77(6): 9681008 . 
[5] Carver J. Boards That Make a Difference: A New Design for Leadership in Nonprofit and Public Organizations (3th edition ed.). San Francisco: Jossey-Bass; 2006.

[6] Nijmeddin W. Assessing governance effectiveness: a model for evaluating governance boards' performance in nonprofit organizations. United States - California: Alliant International University, Fresno; 2007.

[7] Collier J. Measuring and evaluating board performance. Measuring Business Excellence. 2004; 8(3): 12-17.

[8] Kiel GC, Nicholson GJ. Evaluating boards and directors. Corporate Governance: An International Review. 2005; 13(5): 613-631.

[9] Minichilli A, Gabrielsson J, Huse M. Board Evaluations: making a fit between the purpose and the system. Corporate Governance-an International Review. 2007 Jul; 15(4): 609-622.

[10] Swiecicki J. Trends in board performance. Trustee. 2011; 64(4): 24-26.

[11] Cornforth C. What makes boards effective? An examination of the relationships between board inputs, structures, processes and effectiveness in non-profit organisations. Corporate Governancean International Review. 2001 Jul; 9(3): 217-227.

[12] Curran CR, Totten MK. Enhancing board effectiveness. Nursing Economic. 2010; 28(6): 420-422.

[13] Deryl N, Janine S. Managing performance at the top: a balanced scorecard for boards of directors. Journal of Accounting \& Organizational Change. 2011; 7(1): 33-56.

[14] Dulewicz V, Herbert P, MacMillan K. Appraising and developing the effectiveness of boards and their directors. Journal of General Management. 1995; 20(3): 1-19.

[15] Duncan N, Victor D. Inside the "black box": the performance of boards of directors of unlisted companies. Corporate Governance. 2010; 10(3): 293-306.

[16] Epstein MJ, Roy M. Improving the performance of corporate boards: Identifying and measuring the key drivers of success. Journal of General Management. 2004; 29(3): 1-23.

[17] Levrau A, Van den Berghe LAA. Corporate governance and Board Effectiveness: beyond formalism. ICFAI Journal of Corporate Governance. 2007; 6(4): 58-85.

[18] Minichilli A, Zattoni A, Zona F. Making Boards Effective: An Empirical Examination of Board Task Performance. British Journal of Management. 2009 Mar; 20(1): 55-74.

[19] Morgan I. A formalised performance assessment process to improve audit committee performance in South Africa: a conceptual exploration. Southern African Business Review. 2010; 14(2): 89-117.

[20] Nadler DA. Building better boards. Harv Bus Rev. 2004 May; 82(5): 102-111,

[21] Van den Berghe LAA, Levrau A. Evaluating boards of directors: what constitutes a good corporate board? Corporate Governancean International Review. 2004 Oct; 12(4): 461-478.

[22] Wan D, Ong CH. Board structure, process and performance: Evidence from public-listed companies in Singapore. Corporate Governance-an International Review. 2005 Mar; 13(2): 277-290.

[23] Michael SO, Schwartz M, Cravcenco L. Evaluating Highe Education Leadership: Indicators of Trustees' Effectiveness. International Journal of Educational Management. 2000; 14(3) 107-119.
[24] Likins WH. Composition and performnace of governing boards of united methodist-affiliated colleges and universities az reported by chairpersons and presidents. (PhD), Peabody college for teachers of Vanderbit University: Vanderbit University; 1979.

[25] Damari B, Aminlou H, Farzan H, Rahbari M, Alikhani S. Ways to improve the current performance of the boards of trustees of Medical Universities in Iran. Iranian J Publ Health. 2013; 42(1): 36-41.

[26] Kinkel, AG. In search of trust: Identifying indicators of effective public higher education governing boards in the United States., University of Minnesota, United States; 1998.

[27] Myers, REJ. Maintaining the public trust: Core competencies associated with effective governing boards of state multi-campus systems of higher education. (Ph.D.), University of Maryland College Park, United States; 1997.

[28] Schenk, DL. Identifying factors that contribute to the performance of campus-level boards in a multicampus system. Indiana State University; 2003.

[29] CHEPA, Selection and Appointment of Trustees to Public College and University Boards. Center for Higher Education Policy Analysis (CHEPA), University of Southern California, United Stated; 2006.

[30] Sortor, JM. Trustee effectiveness at community colleges: Leadership in an externally controled environment. (PhD), University of Massachusetts Boston; 2002.

[31] Williams SA, Hammons JO. An assessment plan for community college governing boards. Community/Junior College Quarterly of Research and Practice. 1992; 16(2): 141-156.

[32] Holland TP, Chait RP, Taylor BE. Board effectiveness: Identifying and measuring trustee competencies. Research in Higher Education. 1989; 30(4): 435-453.

[33] Chait, R, \& Taylor, B. Evaluating Boards of Trustees: In Theory and in Practice. ASHE Annual Meeting Paper; 1987.

[34] Davis, JA, \& Batchelor, SA. The Effective College and University Board: A Report of a National Survey of Trustees and Presidents. Final Report: Association of Governing Boards of Universities and Colleges, Washington, D.C.; 1974.

[35] Gill M, Flynn RJ, Reissing E. The governance self-assessment checklist: An instrument for assessing board effectiveness. Nonprofit Management and Leadership. 2005; 15(3): 271-94.

[36] Kane NM, Clark JR, Rivenson HL. The internal processes and behavioral dynamics of hospital boards: An exploration of differences between high- and low-performing hospitals. Health Care Management Review. 2008; 34(1): 80-91.

[37] Selim G, Verity J, Brewka E. Board Effectiveness: A literature review. 2009; 103.

[38] Robinson M. Nonprofit boards that work: The end of one size fits all governance. New York: John Wiley; 2001.

[39] Carver, J. Boards That Make a Difference: A New Design for Leadership in Nonprofit and Public Organizations (3th edition ed.). San Francisco: Jossey-Bass; 2006.

[40] Association of governing Boards of Universities and Colleges, Self-study criteria. Washington DC: AGB; 1986.

[41] Conger J, Lawler E, Finegold D. Corporate boards: Strategies for adding value at the top. San Francisco: Jossey-Bass.; 2001.

[42] Nicholson GJ, Kiel GC. A framework for diagnosing board effectiveness. Corporate Governance: An International Review. 2004; 12(4): 442-460. 